Ira Robinson

\title{
1944: A Year in the Life of a Montreal Orthodox Rabbi
}


This article examines the 415 entries in the ledger of Montreal Orthodox Rabbi Yehoshua (Sheea) ha-Levi Herschorn (1893-1969) for 1944 and discusses what they can tell us about Montreal Jews in that critical year. This analysis will enable us to reconstruct in some detail the daily activities of a Montreal Orthodox rabbi. It will also help us to gain some insight into the Jewish community of Montreal in that year in which life in many respects continued relatively normally, and yet the magnitude of the Second World War impinged on the life of Montreal Jews in both expected and unusual ways. This investigation will yield valuable information on the way rabbinical activities in areas such as marriage, divorce, and conversion were undertaken in the Montreal Jewish community in that year. It will thus contribute to a better and more nuanced understanding of the multiplicity of issues and challenges facing Orthodox rabbis, and - by extension - Orthodox Judaism in Montreal in this important transitional period.

Cet article examine les 415 entrées du grand livre $d u$ rabbin orthodoxe montréalais Yehoshua (Sheea) ha-Levi Herschorn (1893-1969) pour l'année civile 1944 et discute de ce qu'elles peuvent nous raconter sur les Juifs de Montréal dans cette année critique. Cette analyse nous permettra de reconstituer en détail les activités quotidiennes d'un rabbin orthodoxe montréalais. Cela nous aidera aussi à mieux comprendre la communauté juive de Montréal cette année-là dans laquelle la vie à bien des égards était poursuivie de façon relativement normale, mais l'ampleur de la Seconde Guerre mondiale a empiété sur la vie des Juifs de Montréal dans des façons attendues et étranges. Cette enquête fournira des informations précieuses sur la façon dont les activités rabbiniques dans des domaines tels que le mariage, le divorce, et la conversion ont été entreprises dans la communauté juive de Montréal cette année-là. Il contribuera ainsi à une compréhension meilleure et plus nuancée de la multiplicité des problèmes et des défis auxquels font face les rabbins orthodoxes, et - par extension - le judaïsme orthodoxe à Montréal en cette période de transition importante.

1944, the focus year for the conference celebrating Rabbi Pinchas Hirschprung's publication of his memoir, was one in which the Second World War was still raging on all fronts. In that year, nonetheless, many people were looking forward to the end of the war and beginning to contemplate what the world might look like after the fighting stopped. Thus in July 1944, assuming an Allied victory, the United Nations Monetary and Financial Conference, with delegates from 44 nations, met at a resort hotel in Bretton Woods, New Hampshire, to agree on a set of new rules for the postwar international monetary system, including the creation of the International Monetary Fund. In August of that year, on the other side of the war, a group of top Nazis and important German corporate leaders, assuming a German defeat, met in a hotel in Strasbourg to begin planning for how they were going to survive the collapse of the Third Reich. ${ }^{2}$ 
For the North American Jewish community, the year 1944 was certainly, as the conference announcement states, "a moment of transition in the history of the North American Jewish community when the magnitude of the still ongoing Nazi destruction of European Jewry was becoming known but was still shrouded in the fog of war, and when the North American Jewish community was beginning to understand the magnitude of the challenges confronting it."3 In the interests of further illuminating the Jewish milieu within which Rabbi Hirschprung lived and worked, I will examine in this article the 4I5 entries in the ledger of Montreal Orthodox Rabbi Yehoshua (Sheea) ha-Levi Herschorn for the calendar year 1944 and discuss what they can tell us about Montreal Jews in that critical year. This analysis will enable us to reconstruct in some detail the daily activities of a Montreal Orthodox rabbi, an important colleague of Rabbi Hirschprung. It will also enable us to gain some insight into the Jewish community that year, one in which life in many respects continued relatively normally, and yet the magnitude of the war impinged on the life of Montreal Jews in both expected and unusual ways. This investigation will yield valuable information on the way rabbinical activities in areas such as marriage, divorce, conversion, and much else were undertaken in the Montreal Jewish community in that year. It will thus contribute to a better and more nuanced understanding of the multiplicity of issues and challenges facing Orthodox rabbis, and by extension, Orthodox Judaism in Montreal in this important transitional period.

\section{Rabbi Sheea Herschorn}

Rabbi Sheea Herschorn was one of the more prominent Orthodox rabbis in Montreal in the year 1944. He was born in the town of Krilovitz, Podolia ${ }^{4}$ in 1893 and received his main rabbinic training from his father. He also acquired a secular education and briefly attended the University of Odessa. He arrived in Montreal in I92I as a refugee from the murderous anti-Jewish violence that swept the Russian Pale of Settlement in the post-First World War period as well as the Soviet persecution of Judaism in his native Ukraine. He served as a rabbi in Montreal for more than four decades, from I92I until his death in 1969.5

Rabbi Herschorn came to Montreal because he had relatives living in the city. When he arrived, he attempted to establish himself as a rabbi in the way numerous other immigrant Orthodox rabbis of his generation had, by supervising a group of kosher slaughterers [shohtim] and kosher butcher shops. The kosher meat industry, and not the spiritual leadership of synagogues, was the major means by which immigrant Orthodox rabbis in North America in that era made their living. Rabbi Herschorn's attempts to establish himself in this way were opposed and he was initially treated as an unwelcome competitor by the more established Orthodox rabbis of Montreal, but within a few years he had become accepted by them as a colleague and ultimately he became a key member of the Montreal Orthodox rabbinate, and specifically of 
the Rabbinical Council [Va'ad ha-Rabbanim] of the Jewish Community Council [Va'ad ha-'Ir] of Montreal, developing a close working relationship with the major Orthodox rabbis of the city, such as Rabbis Yudel Rosenberg (I859-1935) and Hirsch Cohen (I860-I950). ${ }^{6}$

In 1952, two years after the death of Rabbi Hirsch Cohen, who had served as the founding president of the Va'ad ha-Rabbanim of the Va'ad ha-'Ir of Montreal, Rabbi Herschorn was appointed as the second president of the Rabbinical Council and was thus widely recognised as Montreal's chief rabbi. He served as head of the Rabbinical Council until 196I, when he was incapacitated by illness though he was not formally replaced until his death in 1969. He was succeeded in this office by Rabbi Hirschprung. Toward the end of his career, he published a collection of his rabbinic responsa entitled mi-Ma'ayanei Yeshua (Montreal, 1959).

\section{The Ledger}

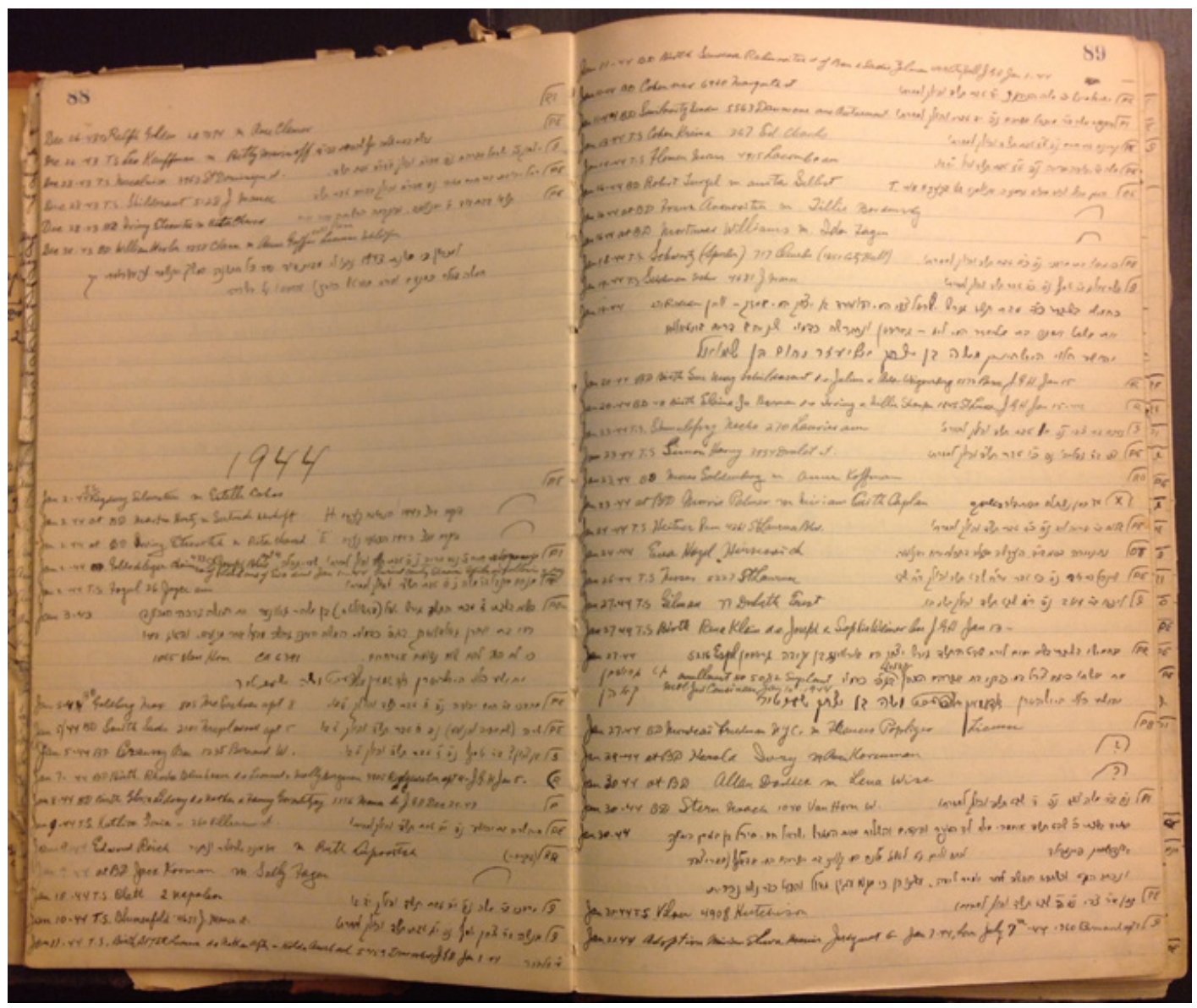

The rabbinic diary of Rabbi Sheea Herschorn for the years 1937-1961. Photo courtesy of Ira Robinson. 
Among Rabbi Herschorn's papers preserved by his only child, Professor Michael Herschorn (1933-2008),, and presently in the author's possession, there is a commercial accounting ledger whose pages measure 8.5 by 14 inches in which he recorded all of his actions in his capacity as rabbi. The first entry in the ledger is dated October 16, 1937, and the last is dated December 7, 1961. Similar rabbinic agendas from the twentieth century are extant, ${ }^{8}$ but to my knowledge none records such a long period of activity, nearly a quarter century, with such painstaking thoroughness. This ledger contains 798 numbered pages, of which 28I pages were actually utilized to record Rabbi Herschorn's varied activities. These rabbinic activities are briefly described in a combination of Hebrew and English in a miniscule and at times difficult to read script. The estimated 9,00o entries in the ledger are generally terse and include the date, the service performed (e.g. marriage), the name of the person or persons involved, and other relevant details including payment for the service, which was recorded in a simple code, enabling us to closely estimate his income from his rabbinical services. ${ }^{9}$ The $4 \mathrm{I} 5$ entries from the year 1944 cover approximately I3 pages of the ledger. ${ }^{10}$

What can these pages tell us about Rabbi Herschorn's activities and concerns in the year 1944? The vast majority of the entries tell the story of the ordinary lifecycle events of the people who made up the Montreal Jewish community. They included:

44 records of births

I Pidyon ha-Ben ${ }^{\text {II }}$

2 Adoptions

7 Conversions to Judaism

7 Announcements of Wedding Banns

I23 Marriages

33 Divorces

6 Halizah Ceremonies $^{12}$

I39 funerals

48 "unveilings" of tombstones. ${ }^{13}$

\section{What We Can Learn From the Ledger}

We can learn much not merely from what is written in the ledger, but also from what does not appear there. There are some significant areas of Rabbi Herschorn's activities that were not in fact mentioned in the ledger. They included, first of all, the numerous activities stemming from his service on the Va'ad ha-Rabbanim, which mostly included kashrut supervision, for which he was paid a salary by the Va'ad ha-'Ir. Secondly, it did not include activities within the synagogue, such as preparing and delivering sermons, for which his congregation paid him a salary. ${ }^{14} \mathrm{The}$ activities that were recorded in the ledger, then, were largely things that he did in his capacity 
as rabbi for which he would have been compensated directly by the party or parties involved. It is likely, therefore, that he kept this ledger to keep track of his non-salary income.

Examining the ledger entries brings us face to face with Montreal Jewish life as it was lived in 1944, and we will note some interesting features of these entries. Then we will deal more specifically with the impact of the war on Rabbi Herschorn's rabbinical practice.

We will start where life begins - with births. The number of births recorded in the ledger - 44 - does not at all constitute the totality of Jewish babies born in Montreal in 1944, but rather only those that were bought to him for recording. Jews came to him and other Montreal rabbis to register their babies' births because the Province of Quebec did not maintain civil birth records in 1944 and, indeed, would not set up a standard provincial system for birth registration until the late twentieth century. Thus, records of birth, marriage, and death were the responsibility of clergy, including rabbis, who had to record them in "Registres d'état civile." At the end of each year, clergymen were obligated to send a copy of their records to the provincial government. ${ }^{15}$ Rabbi Herschorn was one of several rabbis in Montreal who assumed that responsibility. It is noteworthy that all the babies recorded by Herschorn in his ledger in 1944, with but one exception, were girls. Boys would likely have been registered in connection with their circumcision and that aspect of record keeping apparently did not directly go through Herschorn, whereas parents of girls would have gone directly to the rabbi to have their births registered.

The many marriages at which Rabbi Herschorn officiated, I23 in 1944, were generally straightforward affairs except where they involved conversion to Judaism on the part of one of the couple, usually the bride, as we will see in our discussion of conversion. Another complicating issue Herschorn noted in his entries, but without further comment, was the occasional pregnant state of the bride.${ }^{16}$ One more unusual occurrence with respect to marriage which Herschorn encountered on January 3 , 1944, was a couple about to divorce who informed the rabbi that they never had a civil marriage ceremony. Under the provincial laws that governed any Quebec rabbi's conduct in officiating at weddings, there could be no purely "religious" marriages that did not satisfy the civil marriage laws. Thus, it is likely that the couple had married in Eastern Europe where Jews did not always adhere to the civil laws of marriage of their country but merely underwent a Jewish religious ceremony.

There were 33 religious divorces [gittin] supervised by Rabbi Herschorn in 1944 and six ceremonies of halizah, which frees a childless widow from levirate marriage, the biblical obligation of marrying her deceased husband's brother. Rabbinic laws of divorce and haliza are quite complex and are generally supervised only by 
experienced and expert rabbis. ${ }^{17}$ It is thus evident from the large number of divorces he supervised that Herschorn was considered such an expert by his rabbinical colleagues and by Montreal Jews generally. There is no way of knowing with any exactitude whether other Montreal rabbis in this era also supervised divorces, but there is some evidence from Herschorn's records that other prominent Montreal rabbis, like Rabbi Yudel Rosenberg, referred divorce cases to him. ${ }^{18}$ Because the Va'ad ha-'Ir in this era did not have anything like a central register of religious divorces, this ledger constitutes precious evidence of the practice of divorce in Montreal in this era. One 1944 divorce, knowledge of which has entered the public sphere, was that of the parents of the writer Mordecai Richler. The divorce took place on April II, 1944. The ledger entry for this divorce is typical of all the other divorce records supervised by Rabbi Herschorn:

On Sunday, 23 Nisan 5704, Moshe Yiẓhak, called Moshe son of Shemaryahu, called Shmarya, and [also] called Sam Richler divorced his wife Leah, called Lilly, daughter of Yudel, called Yehuda Yudel Rosenberg with a document of separation [get peturin] according to the laws of Moses and Israel. The divorce was arranged in my house at the request of Rabbi [Hirsch] Cohen. [signed] Yehoshua ha-Levi Herschorn, Shaul Alpert, Eliezer Dergatsh.

Normally, divorces supervised by Rabbi Herschorn went smoothly according to established halakhic norms, but on occasion Herschorn records unusual circumstances. Thus, on January 30, 1944, Herschorn noted that he instructed that the divorce document be written even though the woman involved was not present, a serious deviation from the halakhic ideal. In this case, Herschorn noted that he had determined that the future availability and willingness of the husband to grant the divorce was uncertain, and Herschorn was concerned that, if he waited, the woman might become an 'aguna, a woman unable to remarry under rabbinic law: "We did so because the likelihood of desertion ['igun] is great and the husband has already married a non-Jewish woman."

Entries mentioning conversion in 1944 number 7 , nearly all of which were related to marriage with a partner who was born Jewish. There is no evidence in the ledger concerning the preparations the converts underwent before their conversion. Of the seven converts recorded, six were women and one was a man. ${ }^{19}$ Here are some of the circumstances Rabbi Herschorn noted:

January 9, 1944: in recording a marriage Rabbi Herschorn noted that the groom's mother was not Jewish but that he had converted to Judaism.

January 24, 1944: a woman converted to Judaism. She had been separated from her husband at the beginning of January. 
April 5, 1944: a pregnant woman converted to Judaism and was married on the same day.

May II, I944: a woman converted to Judaism. Her father was Jewish and her mother was non-Jewish.

June I2, I944: a woman converted to Judaism. A later entry shows that she was married by Rabbi Herschorn on July 6, I944.

October 30, I944: a woman who had already been married in Toronto was converted to Judaism.

\section{The Impact of the War}

Much if not all of the rabbinic activity evidenced in the ledger would have taken place had there been no war. Wartime did, however, significantly impinge on the experience of Montreal Jews and on the rabbinical practice of Rabbi Herschorn. Here are some examples of the influence of the war from Herschorn's published responsa collection $\mathrm{Mi}-\mathrm{Ma}$ 'ayanei Yeshua:

I. Responsum 5 of Mi-Ma'ayanei Yeshua dates from 1940 and is addressed to Rabbi Gedaliah Felder of Toronto. ${ }^{20}$ It concerns the question whether it is possible to listen on Shabbat to a radio that is turned on and off by an automatic clock. The reason for the question is that "in these days everyone wishes to hear the news of the war with the enemy, may his name be blotted out; the radio is on all day, and there is distress at shutting off this source of news [on Shabbat]."

In this responsum, Rabbi Herschorn showed a great ambivalence. On the one hand, he could not see his way to permit this practice outright on halakhic grounds. On the other hand, he could also not bring himself to say to those Jews who had a great desire to continue listening to the radio war news on Shabbat that they had committed a transgression.

2. Responsum 69 refers to the situation of a group of Jewish refugees from Nazism who, because of their German citizenship, had been arrested in England as "enemy aliens," sent to Canada, and interned in a concentration camp [mahane rikuz] in Canada and whose Torah scroll required repair. ${ }^{21}$ Since Montreal was the nearest large Jewish community, the Jewish inmates of the camp would naturally turn to the Montreal rabbinate for help in this matter.

3. Responsum number 49 dates from the year we are examining, 1944, and refers to the problem, caused by wartime shortages, of finding a kosher for Passover cooking oil for Montreal Jews, the great majority of whom at that point would have been 
concerned about Passover kashrut issues. ${ }^{22}$

Rabbi Herschorn introduced the issue in this way:

In this year, a year of war, may God have mercy on us, there was a great need because they were not able to find the kosher for Passover oil that we use every year, which is cottonseed oil. In this year it was hard to find this oil [even] during the year because the factories that make it prepare it in vessels in which they prepare oil made from non-kosher ingredients.

Rabbi Herschorn described how he along with other local rabbis went to a local factory hoping that they could arrange to manufacture a batch of cottonseed oil for Jewish Passover consumption. However, the factory managers informed them that the factory equipment could not be cleaned to the rabbis' satisfaction. This led to a dispute in which one rabbi declared that he was nonetheless ready under these extenuating conditions to permit cottonseed oil for Jewish Passover consumption without reference to where it was prepared. The majority of rabbis, including Herschorn, did not agree with this proposal but were left seeking a solution. The Montreal rabbinate had been accustomed to instruct Jews who asked them about the kashrut of cooking oil during the rest of the year that they should use Mazola, which was prepared in a factory in which no non-kosher substance was present. Could this oil be used for Passover? In the rabbis' discussion of the issue, a question arose concerning permitting the use of soybean or corn oil on Passover, since corn and soybeans are classified in halakha as "legumes" [kitniot], and as such are not permitted for Passover consumption according to the custom of Ashkenazic Jews. ${ }^{23}$ However, because in the Ukraine (where Herschorn came from) legume [kitniot] oil had traditionally been permitted for Passover, he advocated and the Montreal rabbinate permitted soybean oil for Passover use in 1944 .

4. In I944, Rabbi Herschorn was also involved in a dispute related to the preparation of kosher chickens, a standard source of meat for Montreal Jewish consumers, which was related to wartime conditions. Because of the lack of manpower due to the war, kosher chicken dealers in Montreal had trouble hiring workers to pluck the slaughtered chickens. Chicken dealers therefore came to rely on a plucking machine that required immersion of the chickens in hot water, a procedure that was halakhicly questionable. There was a difference of opinion among the members of the Va'ad ha-Rabbanim on this issue with Herschorn arguing for the permissibility of these chickens given the extenuating circumstances and Rabbi Hirsch Cohen ultimately forbidding their consumption by Jews. ${ }^{24}$

In Rabbi Herschorn's daily ledger, the impact of the war was particularly evident in two cases in which he supervised "conditional divorces" for Canadian soldiers. A 
conditional divorce stipulated that, if the husband did not return from the war within a certain time limit, the divorce document would serve as a valid divorce, and if the husband did return, the document would not retain its validity. It had been used by some Jewish soldiers during the First World War. The soldiers who gave their wives such conditional divorce documents hoped that by this procedure their wives would be able to remarry and not be "tied" to their husbands ['agunot] should the husband became missing in action. ${ }^{25}$ On August 24, 1944, Herschorn recorded his supervision of a divorce document [get] for a soldier which was enacted, on condition that if the husband does not return within the period of two years after the end of the war it will retroactively take effect, and if he does return it will be considered that the document was given to the wife merely for safekeeping and she will duly return it to him. The other conditional divorce Herschorn supervised had an additional unusual circumstance. On October 22, 1944, after the festival of Sukkot had ended, Herschorn recorded what he had done some days earlier. A soldier was about to leave Montreal for the front in India and wished to authorise a conditional divorce for his wife. However, his orders were such that he was obliged to leave Montreal on the first day of the holiday of Sukkot, a time when preparations for divorces are not ordinarily done. Under these circumstances the possibility that the wife would be unable to remarry if the husband became missing in action impelled Herschorn to an unusual decision. As he recorded the incident in his ledger:

The order [for the get] was done on the first day of Sukkot 5705 and the husband left on that day. After consulting with the rabbis of our city we agreed to appoint the scribe, witnesses and agent on the holiday [itself] because of concern that [without this action the wife] might become an 'aguna.

In two cases of halizah that Rabbi Herschorn supervised, the entries specifically state that the husband had died because of the war. Thus, on June 22, 1944, Herschorn supervised a halizah where the husband died "on patrol on the coast of our country according to the certification of our government." Similarly, on August 20, 1944, he recorded that the family had received a letter from the Royal Air Force that the husband had died and was buried in Rotterdam.

The most interesting and unusual way in which the war cast its shadow on the entries in the ledger was the unique case of a man's reconversion to Judaism. Here is the entry with the persons' names omitted:

May 12, 1944: We immersed $X$ who according to his testimony was forced into apostasy [hamara] - May the merciful One save us! - in Portugal in order to obtain a visa. We also immersed his young daughter $Y$ who was born to him through a union with a non-Jewish woman. When she grows up she will be permitted [to marry] a Jew other than a Kohen. 


\section{What We Can Conclude}

Rabbi Herschorn's ledger entries for 1944, whether they directly reflect wartime conditions or simply record the continuation of everyday life on the Canadian home front, constitute a source of considerable historical importance. The entries enable us to discern significant day-to-day details of the lives of hundreds of Montreal Jews with whom the rabbi came into contact in the crucial year of 1944. In order to fully understand the significance of the ig44 entries in Herschorn's ledger, the entire ledger will need to be analyzed in the same detail. Only in that way will we be able to tell in what ways 1944 was either normal or abnormal in Herschorn's rabbinical practice. Even so, the data presented in this article enables us to gain important insights into the religious experience of the Montreal Jewish community in the mid-twentieth century and significantly illuminates the career of one of the community's most important Orthodox rabbis of that period.

1

"The Bretton Woods Conference, 1944," https://2001-2009.state.gov/r/pa/ho/time/ wwii/98681.htm (21November 1944).

2

Adam Lebor, "Revealed: The secret report that shows how the Nazis planned a Fourth Reich ...in the EU," Daily Mail, 9 May 2009, http://www.dailymail.co.uk/news/ article-1179902/Revealed-The-secretreport-shows-Nazis-planned-Fourth-Reich-EU.html\#ixzz4QfrPFeZb; cf. "US Military Intelligence report EW-Pa 128," http://www.cuttingthroughthematrix.com/ articles/Intelligence_Report_EW-Pa_128.html (21November 2016).

3

Flyer for the conference. http://www. concordia.ca/cunews/artsci/jewishstudies/2016/07/11/conference_moment_in_ life_of_community.html (27 March 2017).

4

The town is variously called Murovani Kurylivtsi (Ukrainian), Maravna Krilovitz (Polish), Куриловцы Мурованные (Russian) http://jewua.org/shtetls-of-podolskayagubernia/ (21November 2016).

5

On Rabbi Herschorn, see Ira Robinson, "Herschorn, Joshua (Sheea) Halevy," Encyclopedia Judaica, second edition, 9 (2007), 44.
6

On the Montreal rabbinate and its conflicts in this era, see Ira Robinson, Rabbis and Their Community: Studies in the Immigrant Orthodox Rabbinate in Montreal, 1896-1930 (Calgary, University of Calgary Press, 2007). In the book, Rabbi Herschorn is discussed on pp. 101-115.

\section{7}

On Michael Herschorn, see his obituary in the minutes of the McGill University Senate, April 16, 2008 https://mcgill.ca/senate/files/senate/ minutes_senate_07-08_09.pdf (1November 2016).

8

E.g. the diary of Rabbi Simon Glazer for the year 1909, http://collections. americanjewisharchives.org/ms/ms0269/ ms0269.html\# 21November 2016).

9

The code substituted letters for numbers. A ten-letter word "profitable" represented, in order, the nine numerals plus 0 . Thus an annotation "PE" represents a payment of $\$ 10.00$, and “Rl" would mean $\$ 25.00$.

10

See pp. 88-101.

11

Shoshana Matzner-Beckerman, "The Meaning of Pidyon HaBen: Redemption of the first-born son is an act of gratitude and humility," http:// www.myjewishlearning.com/article/themeaning-of-pidyon-haben/ (27 March 2017). 
12

On the ceremony, see Catherine Hezser, "The Halitzah Shoe: Between Female Subjugation and Symbolic Emasculation," in Jews and Shoes, ed. Edna Nahshon (New York, Berg Publishers, 2008), 47-63.

\section{3}

Barbara Binder Kadden, "The Tombstone, the Unveiling, and Visiting the Grave: What happens at the Jewish cemetery," http://www. myjewishlearning.com/article/the-tombstonethe-unveiling-and-visiting-the-grave/ (27 March 2017).

\section{4}

For an analysis of one of Rabbi Herschorn's sermons and the controversy it ignited, see Ira Robinson, “'The Other Side of the Coin': The Anatomy of a Public Controversy in the Montreal Jewish Community, 1931," Studies in Religion 40, no. 3 (September 2011): 271 - 282.

\section{5}

For a listing of Montreal rabbis who had such responsibilities, see "Rabbis of Quebec, Canada," http://www.jewishgen.org/Rabbinic/ databases/quebec.htm\#H (27 November 2016).

16

April 5 and September 17, 1944. This might possibly reflect a change in sexual mores that some observers attributed to war conditions.

17

Cf. Talmud Bavli Kiddushin 6a.

18

One divorce case in Rabbi Herschorn's files in the author's possession contains a letter from the Rabbinate of Warsaw, Poland, addressed to Rabbi Rosenberg.

19

One conversion was recorded on December 4 , 1944, with no special circumstances noted.

20

S. Herschorn, Mi-Ma'ayanei Yeshua (Montreal, 1959), 12a-17b, 23-34. On Rabbi Felder, see Richard Menkis, “Felder, Gedaliah," http:// www.jewishvirtuallibrary.org/jsource/judaica/ ejud_0002_0006_0_06362.html (22 November 2016).

\section{1}

Ibid., pp. 92b-93b, 184-186. The refugee camps in Canada were not actually concentration camps. For a study of the German-Jewish internees in Canada during World War II and the conditions of their internment in Canada, see Paula Draper, "The Accidental Immigrants: Canada and the Interned Refugees" University of Toronto doctoral dissertation 1983, and Paula Draper, "The Accidental Immigrants: Canada and the Interned Refugees," Canadian Jewish Historical Society Journal 2 (1978): 1-38, 80-112.

22 Ibid., pp. 72a-73a, 143-145.

\section{3}

On this issue, see Orthodox Union, "What is Kitniyot?", 2008, http://www.kashrut.com/ Passover/Kitniyot/ (27 March, 2017).

\section{4}

Steven Lapidus, "Orthodoxy in Transition: The Vaad Ha'ir of Montreal in the Twentieth Century," PhD dissertation, Concordia University, 2011, 58-62.

\section{5}

Michele Alperin, "Conditional Divorce," http://www.myjewishlearning.com/article/ conditional-divorce/ (21 November 2016]. 